\title{
EFEKTIVITAS PEMBERIAN ANTIOKSIDAN SINTETIK \\ TERHADAP KADAR SUPEROXIDE DISMUTASE (SOD) \\ PADA AKTIVITAS FISIK ANAEROBIK
}

\author{
Apriani $^{1}$, Hardi Darmawan ${ }^{2}$, Theodorus ${ }^{3}$
}

Fisiologi Kedokteran Program Studi Magister IImu Biomedik Fakultas Kedokteran Universitas Sriwijaya Palembang ${ }^{1}$, Dosen Fisiologi Kedokteran², Dosen Metodologi Penelitian³.

\begin{abstract}
ABSTRAK
Latar Belakang: Aktivitas fisik anaerobik dapat mengakibatkan terbentuknya radikal bebas sehingga dapat menyebabkan terjadinya stres oksidatif. Untuk mencegah terjadinya stres oksidatif diperlukan antioksidan sintetik. Salah satu contohnya adalah glisodin. Penelitian ini bertujuan untuk mengetahui efektivitas pemberian antioksidan sintetik dan plasebo terhadap kadar SOD pada aktivitas fisik anaerobik.

Metode: Penelitian Randomised Controlled Trials, double blind dilaksanakan di Lapangan Olahraga Universitas Sriwijaya Bukit Palembang, sedangkan untuk pemeriksaan kadar SOD di Laboratorium Biologi Molekuler Universitas Sriwijaya Palembang. Jumlah sampel dalam penelitian ini sebanyak 34 sampel yang dibagi menjadi 2 kelompok yaitu kelompok perlakuan dengan pemberian antioksidan sintetik (glisodin) sebanyak 2 kapsul (500 IU) dan kelompok plasebo dengan pemberian 2 kapsul kosong dengan warna, bentuk dan ukuran yang sama dengan glisodin.

Hasil: Hasil penelitian melalui paired t-test menunjukkan bahwa rerata kadar SOD (dalam satuan Dalton) sebelum perlakuan pada kelompok glisodin $0,066 \pm 0,059$ dan sesudah perlakuan 1,135 \pm 0,959 , dengan

$p$ value $=0,000$, sedangkan pada kelompok plasebo sebelum perlakuan $0,059 \pm 0,064$ dan sesudah perlakuan $0,343 \pm 0,224$, dengan $p$ value $=0,000$. Hasil penelitian ini menunjukkan bahwa terjadi peningkatan kadar SOD yang signifikan pada kelompok perlakuan setelah diberikan antioksidan sintetik (glisodin).
\end{abstract}

Kesimpulan: Ada perbedaan efektivitas pemberian antioksidan sintetik dan plasebo terhadap kadar SOD pada aktivitas fisik anaerobik.

Kata Kunci: Superoxide Dismutase (SOD), antioksidan sintetik, glisodin, aktivitas fisik anaerobik 


\section{PENDAHULUAN}

Aktivitas fisik anaerobik adalah aktivitas fisik yang dalam proses metabolisme pembentukan energi tidak menggunakan oksigen. Energi dihasilkan dari pembentukan ATP melalui sumber energi yang berasal dari kreatinfosfat dan glikogen (Hermina et al., 2004). Aktivitas fisik dengan intensitas maksimal dapat meningkatkan konsumsi oksigen 100 - 200 kali lipat karena terjadi peningkatan metabolisme di dalam tubuh. Peningkatan penggunaan oksigen terutama oleh otot-otot yang berkontraksi, menyebabkan terjadinya peningkatan kebocoran elektron dari mitokondria yang akan menjadi SOR (Senyawa Oksigen Reaktif) (Clarkson \& Thompson, 2000). Umumnya $2-5 \%$ dari oksigen yang digunakan dalam proses metabolisme di dalam tubuh akan menjadi ion superoksid sehingga saat aktivitas fisik berat terjadi peningkatan produksi radikal bebas (Chevion, 2003).

Dalam keadaan normal radikal bebas yang diproduksi di dalam tubuh akan dinetralisir oleh antioksidan yang ada di dalam tubuh, antara lain oleh antioksidan Superoxide Dismutase (SOD). Apabila kadar radikal bebas terlalu tinggi seperti saat melakukan latihan aerobik maksimal dan latihan fisik anaerobik, maka kemampuan dari antioksidan endogen tidak memadai untuk menetralisir radikal bebas sehingga terjadi keadaan yang tidak seimbang antara radikal bebas dengan antioksidan yang disebut stres oksidatif (Clarkson, 2000; Leeuwenburgh, 2001: Harjanto, 2004 dan Halliwell, Gutteridge, 2007 cit Kurniawaty, 2014).

Stres oksidatif timbul akibat reaksi metabolik yang menggunakan oksigen dan mengakibatkan gangguan pada keseimbangan antara oksidan dan antioksidan (Suarsana et al,
2013). Antioksidan adalah zat yang dapat melawan pengaruh bahaya dari radikal bebas yang terbentuk sebagai hasil metabolisme oksidatif, yaitu hasil dari reaksi-reaksi kimia dan proses metabolik yang terjadi di dalam tubuh (Rohmatussolihat, 2009).

Berdasarkan sumber perolehannya ada 2 macam antioksidan, yaitu antioksidan alami dan antioksidan buatan (sintetik). Antioksidan alami umumnya berupa senyawa-senyawa fenolik yang terdapat dalam berbagai tanaman, sedangkan antioksidan sintetik, seperti Butil Hidroksi Anisol (BHA) dan Butil Hidroksi Toluen (BHT), merupakan antioksidan yang dirancang berdasarkan mekanisme penghambatan radikal oleh antioksidan alami (Yunita et al, 2012).

Salah satu contoh antioksidan sintetik adalah glisodin. Glisodin adalah suplemen antioksidan yang terbuat dari ekstrak melon dan gliadin. Ekstrak melon yang terkandung dalam glisodin merupakan sumber yang kaya enzim antioksidan SOD (Superoxide Dismutase). Melon mengandung gula yang tinggi dan lycopene yang berfungsi sebagai anti kanker. Melon merah dan orange juga mengandung carotenoid yang dapat melindungi sel tubuh terhadap kerusakan radikal bebas dan dapat diubah menjadi vitamin A dalam tubuh (Siswanto, 2010). SOD yang terkandung di dalam buah melon merupakan antioksidan pertama yang dimobilisasi oleh sel sebagai mekanisme pertahanan tubuh. SOD diperkirakan lebih kuat dibanding vitamin antioksidan karena SOD mengaktivasi produksi antioksidan tubuh sendiri termasuk katalase dan glutation peroksidase (Arief, 2010). Selain mengandung ekstrak melon, glisodin juga mengandung gliadin yang merupakan glikoprotein yang terdapat di dalam gandum 
dan sereal lainnya. Gliadin digunakan untuk melindungi enzim (misalnya SOD) terhadap asam lambung (European Food Safety Authority, 2010).

\section{METODE PENELITIAN}

Jenis penelitian ini adalah penelitian uji klinik berpembanding dalam bentuk double blind. Penelitian ini dilaksanakan di Lapangan Olahraga Universitas Sriwijaya Bukit Palembang pada tanggal 21 Maret 2015, sedangkan untuk pemeriksaan kadar SOD di Laboratorium Biologi Molekuler Universitas Sriwijaya Palembang pada tanggal 11-12 April 2015. Jumlah sampel dalam penelitian ini sebanyak 34 sampel yang dibagi menjadi 2 kelompok yaitu kelompok perlakuan dengan pemberian antioksidan sintetik (glisodin) sebanyak 2 kapsul (500 IU) dan kelompok plasebo dengan pemberian 2 kapsul kosong dengan warna, bentuk dan ukuran yang sama dengan glisodin.

Alat yang dipakai dalam penelitian ini adalah spektrofotometer, vortex, cuvette, mikropipet beserta tip kuning dan biru, gelas ukur dan centrifuge. Bahan SOD adalah Mixed Subtrate $5 \times 20 \mathrm{ml}$, Buffer $1 \times 105 \mathrm{ml}$, Xanthine Oxidase $3 \times 10 \mathrm{ml}$, Cal Standard $5 \times 10 \mathrm{ml}$.

\section{Pemeriksaan Kadar SOD}

Sampel darah dimasukkan ke dalam tabung reaksi tanpa antikoagulan diendapkan selama 30 menit pada suhu kamar kemudian dipindahkan dalam tabung centrifuge dan dicentrifugasi dengan kecepatan 3000 rpm selama 10 menit. Serum diambil dengan mikropipet sebanyak $0,05 \mathrm{ml}$ kemudian dimasukkan ke dalam cuvette. Sampel serum sebanyak $0,05 \mathrm{ml}$ ditambah $1,7 \mathrm{ml}$ mixed substrate, ditambah $0,25 \mathrm{ml}$ xanthine oxidase kemudian dihomogenkan dengan vortex. Sampel kemudian diukur absorbansinya dengan spektrofotometer pada panjang gelombang (505 nm). Baca hasil absorbansi A1 setelah 30 detik dan terakhir baca absorbansi A2 setelah 3 menit.

\section{HASIL DAN PEMBAHASAN}

\section{Karakteristik Subjek Penelitian}

Pada penelitian ini karakteristik subjek penelitian meliputi umur, tinggi badan, berat badan, tekanan darah sistolik, tekanan darah diastolik, nadi dan frekuensi pernafasan pada kelompok perlakuan (pemberian glisodin) dan kelompok plasebo/ pembanding. Hasil penelitian ini menunjukkan bahwa tidak ada perbedaan yang bermakna $(p>0,05)$ sehingga kedua kelompok dapat dibandingkan. Adapun data tentang karakteristik tersebut dicantumkan pada tabel berikut:

Tabel 1. Homogenitas Kelompok Perlakuan (Glisodin) dan Plasebo

\begin{tabular}{lccc}
\hline \multicolumn{1}{c}{ Variabel } & \multicolumn{2}{c}{ Kelompok } & $P$ \\
\cline { 2 - 3 } & Glisodin & Plasebo & \\
\hline Umur (th) & $18,82 \pm 0,883$ & $18,76 \pm 0,831$ & 0,670 \\
Tinggi Badan (cm) & $169,12 \pm 5,207$ & $167,18 \pm 6,095$ & 0,671 \\
TD Sistolik (mmHg) & $125,88 \pm 8,703$ & $115,29 \pm 9,432$ & 0,906 \\
TD Diastolik (mmHg) & $75,88 \pm 5,073$ & $73,53 \pm 4,926$ & 0,508 \\
Nadi (x/menit) & $78,00 \pm 5,545$ & $79,24 \pm 3,993$ & 0,169 \\
RR (x/menit) & $20,12 \pm 1,219$ & $20,71 \pm 1,532$ & 0,357 \\
\hline Levene Test $p \geq 0,05$ & & &
\end{tabular}


Umur subjek penelitian/partisipan ditentukan dalam kriteria inklusi yakni 18-20 tahun, supaya peserta yang terpilih mempunyai daya tahan kardiovaskuler yang maksimal untuk dapat mengikuti aktivitas fisik anaerobik. Selain itu, batasan umur tersebut ditentukan untuk homogenitas umur partisipan. Hal ini sejalan dengan yang dilakukan oleh Chevion et al (2008) yang melakukan penelitian serupa pada 31 orang laki-laki sehat dengan rata-rata umur 19 tahun.

Umur mempengaruhi hampir semua komponen kondisi fisik. Daya tahan kardiovaskuler yang berhubungan dengan stamina menunjukkan suatu tendensi meningkat pada masa anak-anak sampai sekitar dua puluh tahun dan mencapai maksimal di usia 20 sampai 30 tahun. Daya tahan tersebut akan makin menurun sejalan dengan bertambahnya usia, dengan penurunan 8-10\% perdekade untuk individu yang tidak aktif, sedangkan untuk individu yang aktif penurunan tersebut 4-5\% perdekade (Mardiah, 2013).

Aktivitas fisik akan menyebabkan perubahan-perubahan pada faal tubuh manusia, baik bersifat sementara maupun yang bersifat menetap. Aktivitas fisik dengan intensitas tinggi akan mempengaruhi daya tahan kardiovaskuler dan respirasi. Daya tahan kardiovaskuler dan respirasi itu meliputi: tekanan darah sistolik, tekanan darah diastolik, denyut nadi dan frekuensi pernafasan. Dalam melakukan aktivitas fisik anaerobik subjek penelitian harus mencapai daya tahan kardiovaskuler yang maksimal.

\section{Tabel 2. Perbedaan Berat Badan pada Kelompok Perlakuan (Glisodin) dan Kelompok Plasebo}

\begin{tabular}{cccccccc}
\hline \multirow{2}{*}{ Variabel } & \multicolumn{2}{c}{ Glisodin } & & \multicolumn{2}{c}{ Plasebo } & $p^{*}$ \\
\cline { 2 - 3 } & Sebelum & Setelah & & Sebelum & Setelah & \\
\hline Berat Badan & $62,47 \pm 7,906$ & $61,67 \pm 7,892$ & 0,993 & $59,70 \pm 7,848$ & $59,08 \pm 7,729$ & 0,975 \\
\hline
\end{tabular}

Levene Test, $p=0,05$

Hasil penelitian di atas menunjukkan bahwa terjadi penurunan berat badan pada kedua kelompok. Pada kelompok perlakuan (Glisodin) penurunan berat badannya sekitar $1,28 \%$, sedangkan pada kelompok plasebo penurunan berat badannya sekitar $1,03 \%$. Hal ini dikarenakan pada aktivitas fisik akan terjadi pengeluaran cairan yang berlebih lewat keringat. Apabila cairan yang keluar berlebihan dan tidak ada cairan yang masuk ke dalam tubuh maka kita akan mengalami dehidrasi. Dehidrasi dapat diukur atau diamati dengan menimbang berat badan sebelum dan setelah beraktivitas.
Hasil ini berbeda dengan penelitian yang dilakukan oleh Wadud (2013), yang menyatakan bahwa ada perbedaan berat badan yang bermakna sebelum dan sesudah aktivitas fisik pada kelompok aerobik $(p=0,000)$, dan kelompok anaerobik $(p=0,001)$. Begitu pula dengan penelitian yang dilakukan oleh Sientina (2012) mengatakan bahwa ada perubahan yang bermakna $(p=0,000)$ pada peserta senam aerobik sebelum dan sesudah mengikuti senam aerobik.

Menurut penulis, dehidrasi yang disebabkan karena kehilangan cairan yang berlebih dan tidak disertai pemasukan cairan 
yang adekuat dapat menyebabkan terjadinya peningkatan suhu tubuh. Peningkatan suhu tubuh yang terjadi pada aktivitas fisik dapat berpotensi meningkatkan pembentukan senyawa radikal bebas. Jika jumlah radikal bebas yang terbentuk melebihi dari kadar antioksidan yang ada di dalam tubuh kita maka dapat menyebabkan terjadinya stres oksidatif. Stres oksidatif ditandai dengan peningkatan kadar Malondealdehyde (MDA) dan penurunan kadar Superoxide Dismutase (SOD).

\section{Uji Normalitas Data}

Uji normalitas data dilakukan untuk melihat apakah data (kadar SOD) sebelum perlakuan berdistribusi normal atau tidak. Apabila data terditribusi normal maka analisis uji t-test menggunakan uji parametrik sedangkan jika data tidak terdistribusi normal maka analisis yang digunakan uji non parametrik. Hasil analisis dapat dilihat sebagai berikut:

Tabel 4.3 Uji Normalitas Kadar SOD pada Kelompok Perlakuan (Glisodin) dan Plasebo

\begin{tabular}{|c|c|c|c|}
\hline \multirow{2}{*}{ Variabel } & \multicolumn{2}{|c|}{ Kelompok } & \multirow{2}{*}{$P$} \\
\hline & Glisodin & Plasebo & \\
\hline Kadar SOD & $0,066 \pm 0,0591$ & $0,059 \pm 0,064$ & 0,701 \\
\hline
\end{tabular}

Levene Test, $p$ value $\geq 0,05$

Hasil uji normalitas menunjukkan bahwa kadar SOD sebelum perlakuan pada kelompok Glisodin yaitu $0,066 \pm 0,0591$, sedangkan pada kelompok Plasebo kadar SOD sebelum perlakuan yaitu $0,059 \pm 0,064$. Hasil uji statistik dengan menggunakan levene test didapatkan $p$ value $=0,701$. Hal ini menunjukkan bahwa kadar SOD berdistribusi normal $(p>0,05)$.

Berdasarkan data di atas juga didapatkan hasil bahwa setelah aktivitas fisik anaerobik yaitu lari sprint sejauh $2 \times 60$ meter ini terjadi penurunan kadar Superoxide Dismutase (SOD) baik pada kelompok perlakuan (Glisodin) maupun pada kelompok plasebo. Terjadinya penurunan kadar SOD ini dikarenakan aktivitas fisik anaerobik dapat menyebabkan terjadinya peningkatan kadar MDA yang biasanya digunakan sebagai biomarker biologis peroksidasi lipid untuk menilai stress oksidatif. Jika terjadi stres oksidatif, maka radikal bebas yang terbentuk jumlahnya sangat meningkat atau jumlah radikal bebas akan melebihi kemampuan sistem pertahanan tubuh.
Hasil penelitian ini sesuai dengan Penelitian Aslan (1998) yang menemukan bahwa aktivitas fisik akut menyebabkan stres oksidatif dengan meningkatnya peroksidasi lipid dan tidak efisiennya sistem pertahanan antioksidan. Aktivitas enzim antioksidan menurun setelah latihan akut, diketahui juga bahwa hidrogen peroksida dapat menghambat aktivitas superoksida dismutase.

\section{Perbandingan Efektivitas Pemberian Antioksidan Sintetik (Glisodin) dan Plasebo pada Kelompok Perlakuan dan Plasebo \\ Pada hasil uji statistik menunjukkan} bahwa rata-rata kadar SOD sebelum perlakuan pada kelompok glisodin 0,066 $\pm 0,059$ dan setelah perlakuan yaitu $1,135 \pm 0,959$, hasil uji statistik dengan menggunakan uji paired t-test didapatkan $p=0,000$, sedangkan pada kelompok plasebo rata-rata kadar SOD sebelum perlakuan $0,059 \pm 0,064$ dan setelah perlakuan yaitu $0,343 \pm 0,224$. Hasil uji statistik didapatkan $p=0,000$. 
Hasil perbedaan kadar SOD sebelum dan setelah perlakuan pada kelompok perlakuan dan plasebo dapat dilihat dari tabel berikut ini:

Tabel 3. Perbandingan Efektivitas Pemberian Antioksidan Sintetik (Glisodin) dan Plasebo pada Kelompok Perlakuan dan Plasebo

\begin{tabular}{lccccccc}
\hline \multirow{2}{*}{ Variabel } & \multicolumn{3}{c}{ Glisodin } & \multicolumn{3}{c}{ Plasebo } & \multirow{2}{*}{$\mathrm{P}^{\star *}$} \\
\cline { 2 - 7 } & Sebelum & Setelah & $\mathrm{P}^{*}$ & Sebelum & Setelah & $\mathrm{P}^{*}$ & \\
\hline Kadar & $0,066 \pm$ & $1,135 \pm$ & 0,00 & $0,059 \pm 0,064$ & $0,343 \pm$ & 0,00 & 0,00 \\
SOD & 0,059 & 0,959 & 0 & 0,224 & 0 & 0 \\
\hline
\end{tabular}

$p^{*}=$ Uji t- berpasangan

$p^{\star \star}=U j \mathrm{j}$ t tidak berpasangan

Berdasarkan tabel di atas didapatkan bahwa ada perbedaan efektivitas pemberian antioksidan sintetik (glisodin) antara kelompok perlakuan dan kelompok plasebo setelah perlakuan dengan nilai $p$ value $=0,000$ $(p<0,05)$. Hasil penelitian di atas menunjukkan bahwa terjadi peningkatan kadar SOD yang signifikan setelah pemberian antioksidan sintetik yaitu glisodin pada kelompok perlakuan, sedangkan pada kelompok plasebo terjadi peningkatan kadar SOD tetapi tidak signifikan / bermakna.

Hasil penelitian ini sejalan dengan hasil penelitian Stejnborn (2011) pada anggota tim dayung nasional Polandia yang menyatakan bahwa aktivitas SOD lebih tinggi secara signifikan ( $p=0,0037$ ) pada kelompok yang menerima glisodin dibanding pada kelompok plasebo. Glisodin terbukti dapat meningkatkan kadar antioksidan.

Peningkatan kadar SOD pada kelompok perlakuan kemungkinan disebabkan karena senyawa yang terkandung didalam glisodin bekerja sebagai antioksidan dengan cara mendonorkan elektronnya kepada radikal bebas. Glisodin merupakan suplemen yang terbuat dari ekstrak melon dan gliadin. Menurut Meinvielle (2005) glisodin sebagai suplemen antioksidan untuk memperoleh efek perlindungan terhadap gangguan sistem pertahanan alamiah tubuh: fase penyembuhan, terpapar sinar matahari atau ultraviolet secara terus menerus, atau latihan fisik yang berat (setelah pertandingan olahraga atau untuk orang yang berolahraga pada saat - saat tertentu). Ekstrak melon banyak mengandung gula yang tinggi dan lycopene yang berfungsi sebagai anti kanker. Melon merah dan orange juga mengandung carotenoid yang dapat melindungi sel tubuh terhadap kerusakan radikal bebas dan dapat diubah menjadi vitamin A dalam tubuh (Siswanto, 2010).

Hasil ini didukung oleh penelitian yang serupa oleh Sulistyowati (2006) yang menunjukkan bahwa dengan pemberian likopen dosis 0,$36 ; 0,72$; dan 1,08 mg/ekor/hari terbukti dapat meningkatkan status antioksidan tikus (Rattus norvegicus galur Sprague Dawley) hiperkolesterolemik.

Peningkatan kadar SOD pada kelompok plasebo kemungkinan dikarenakan adanya jeda waktu istirahat (pemulihan pasif). Jarak antara pengambilan darah pertama dan kedua adalah 70 menit, sedangkan untuk pemulihan asam laktat diperlukan waktu 60 menit. Jika asam laktat menurun atau berkurang, maka $\mathrm{pH}$ darah dan otot akan kembali ke keadaan semula sebelum dilakukan aktivitas fisik sehingga pembentukan radikal bebas tidak terjadi.

Pada penelitian ini didapatkan hasil bahwa pada aktivitas fisik anaerobik setelah 70 menit pemberian antioksidan sintetik yaitu glisodin sebanyak 2 kapsul (500 IU) dapat 
meningkatkan kadar Superoxide Dismutase (SOD). Berdasarkan hasil Independent t-tes menunjukkan bahwa ada perbedaan efektivitas pemberian antioksidan sintetik dan plasebo terhadap kadar Superoxide Dismutase (SOD) pada aktivitas fisik anaerobik. Hal ini berarti $\mathrm{Ha}$ diterima.

\section{KESIMPULAN}

Berdasarkan uraian hasil dan pembahasan diatas maka dapat disimpulkan bahwa:

1. Rerata kadar SOD sebelum perlakuan pada kelompok glisodin yaitu 0,066 $\pm 0,0591$, sedangkan pada kelompok plasebo yaitu $0,059 \pm 0,064$. Hasil ini menunjukkan bahwa terjadi penurunan kadar SOD setelah aktivitas fisik anaerobik.

2. Rerata kadar SOD setelah perlakuan pada kelompok glisodin yaitu 1,135 $\pm 0,959$, sedangkan pada kelompok plasebo yaitu $0,343 \pm 0,224$. Hasil ini menunjukkan bahwa terjadi peningkatan kadar antioksidan SOD setelah pemberian glisodin pada kelompok perlakuan (Glisodin).

3. Ada perbedaan efektivitas pemberian antioksidan sintetik dan plasebo terhadap kadar Superoxide Dismutase (SOD) pada aktivitas fisik anaerobik.

\section{SARAN}

1. Untuk peneliti selanjutnya diharapkan menggunakan atlet sebagai sampel penelitiannya.

2. Penelitian ini dapat dikembangkan lagi dengan menggunakan variabel lain yang dapat mempengaruhi Kadar SOD atau perlu dilakukan penelitian tentang antioksidan endogen lain seperti GPX, katalase dan antioksidan lainnya.
3. Penelitian ini membuktikan bahwa aktivitas fisik anaerobik dapat menyebabkan penurunan kadar antioksidan SOD. Untuk itu bagi masyarakat setelah melakukan aktivitas fisik anaerobik sebaiknya mengkonsumsi antioksidan, baik itu antioksidan alami maupun sintetik.

\section{DAFTAR PUSTAKA}

Almuktabar. 2008. Perspektif Fisiologi Suatu Analisis Kelelahan.

(http://www.iptekor.com/doc/11 2 1.pdf, diakses 27 November 2014.

Arief, Irfan. 2010. Ekstrak Melon Membantu Mencegah Obesitas. National Cardiovascular Center Harapan Kita

Arsana I.N. 2014. Ekstrak Kulit Buah Manggis (Garcinia Mangostana L.) dan Pelatihan Fisik Menurunkan Stres Oksidatif Pada Tikus Wistar (Rattus Norvegicus) Selama Aktivitas Fisik Maksimal. Disertasi Program Doktor Program Studi IImu Kedokteran Program Pascasarjana Universitas Udayana Denpasar

Arts, M.J.T.J., Haenen, G.R.M.M., Voss, H.P. dan Bast, A. (2004). Antioxidant Capacity of Reaction Products Limits the Applicability of the Trolox Equivalent Antioxidant Capacity (TEAC) Assay. Food and Chemical Toxicology, 42, 4549.

Asj'ari, S.R. 2004. Misteri Umur Panjang, Tinjauan dari Aspek Biokimia Gizi Molekuler : Pidato Pengukuhan Jabatan Guru Besar dalam IImu Biokimia. Yogyakarta : FK UGM.

Aslan, R., Sekeroglu, M.R., Tarakcioglu, M., Bayiroglu, F. and Meral, I. 1998. Effect of Acute and Regular Exercise on 
Antioxidative Enzymes, Tissue Dam-age

Markers and Membran Lipid Peroxidation

of Erythrocytes in Sedentary Students.

Journal of Medical Sciences, 28: 411-414

Astuti, S. 2008. Isoflavon Kedelai dan Potensinya Sebagai Penangkap Radikal Bebas (Soybean Isoflavone and Its Potentially as Scavenger Free Radicals). Jurnal Teknologi Industri dan Hasil Pertanian Volume 13, No. 2, September 2008

Bangso, et.all. 1995. Lactate and Ion $\mathrm{H}^{+}$ Effluxes From Human Scletal Muscle During Intense Dinamic Exercise. J. Phy. 46:115-133.

Battineli, T. 2000. Physique, Fitness, and Performance. Florida: CRC Fress

Bohm V, Bitsch R. Intestinal Absorption of Lycopene from Different Matrices and Interactions or Other Carotenoids, The Lipid Status, and The Antioxidant Capacity of Human Plasma. Eur J Nutr 1999;38(3):118-25

Boma, Whikota. 2007. Manfaat Melon. Jurnal Sains Vol. 2 No. 2. Desember 2007: 61-89

Bompa. T. O (1990) Theory and Methodology of Training, Toronto, Ontorio Canada, Kendall/Hunt Publishing Company

Bompa. 1999. Periodization: Theory and Methodology of Training. New York University

Borowski. L, 1998. Sweating : Students Find Exercise and Dehydration to be Hot Topics in Chemistry. The Science Teacher Journal

Cherubini A, Polidori C, Bedetti C, Ercolani S, Senin U, Mecocci P. Assosiation between ischemic stroke and increased oxidative stress. Perugia. 1999

Chevion S et al. 2003. Plasma antioxidant status and cell injury after severe physical exercise. Proc.Nati.Acad.Sci.USA, Vol 100, Issue 9,5119-5123. Diakses pada Tanggal 28 Februari 2013

Clarkson. P.M and H.S Thompson. 2000. Antioksidants: What Role Do Play in Physical Activity and Health. Am J Clin Nutr. 72(2):637S-646S

Cooper, K.H. (2000). Antioxidant Revolution, Tennessee, Thomas Nelson Publishers

Dalimartha, S. dan Soedibyo, M. (1999). Awet Muda Dengan Tumbuhan Obat dan Diet Suplemen Trubus Agriwidya. Jakarta. hal. 36-40.

Douglas, J.C., Lawrance, E.A. \& Scott, J.M., 2000. National Athletic Trainers Association Position Statement: Fluid Replacement for Athletes. Journal of Athletic Training. 35: 212-224

Duharman, T. Panjaitan, Prasetyo, B., Limantara, L. 2008. Peranan Karotenoid Alami dalam Menangkal Radikal Bebas di dalam Tubuh. Program Magister Biologi, Universitas Kristen Satya Wacana \& Ma Chung Research Center, Universitas Ma Chung, Malang

European Food Safety Authority (EFSA), 2010. Scientific Opinion on the substantiation of health claims related to superoxide dismutase (SOD) and protection of DNA, proteins and lipids from oxidative damage, protection of the skin from photo-oxidative (UV-induced) damage reduction of muscle fatigue during exercise, and "effects on immune 
system"pursuant to Article of Regulation.

Parma, Italy

Flohe, L and Gunzher, W. A. 1984. Assay of Glutathionne Peroxides. Methods

Enzymol. 105: p. 114-120

Flora, R. 2005. Efektivitas Minuman Suplemen dalam Mengembalikan Keseimbangan Cairan Tubuh pada Dehidrasi Akibat Aerobik Intensitas Sedang. Tesis Program Pascasarjana Universitas Gajah Mada Yogyakarta

Fox, E.L., Bowers, R.W., Foss, M.L. 1993 The Physiological Basis For Exercise And Sport, USA, Brown \& Benchmark Publ

Fox, E.L., Bowers, R.W., Foss, M.L. 1998. The Physiological Basis of Physical Education and Athletics ( $4^{\text {th }} E d$ ). Philadelphia, Saunders College

Gomez- Cabrera, M. C., Martinez, A., Santangelo, G., Pallardo, F.V., Sastre, J., dan Vin, J. 2006. Oxidative Stress in Marathon Runner. Interest of Antioxidant Supplementation. British Journal of Nutrition. 96 (Suppl.1): 3-3

Guyton, A. C. \& Hall, J. E. 2007. Buku Ajar Fisiologi Kedokteran. Edisi ke-9. Penerbit Buku Kedokteran: EGC. Jakarta

Halliwel, B. dan Gutteridge, J.M.C. (1999). Free Radical in Biology and Medicine. $3^{\text {rd }}$ ed. Oxford University Press, 23-31, 105-115

Halliwell, B. \& Whiteman, M. 1999. Measuring reactive species and oxidative damage in vivo and in cell culture: how should you do it and what do the results mean? Br J Pharmacol, 142, 231-55

Hairrudin \& Helianti. 2009. Efek Protektif Propolis dalam Mencegah Stres Oksidatif Akibat Aktifitas Fisik Berat (Swimming Stress)
Harjanto. 2004. Petanda Biologis dan Faktor yang Mempengaruhi Derajat Stress Oksidatif pada Latihan Olahraga Aerobik Sesaat. Disertasi Surabaya Program Pascasarjana Universitas Airlangga

Harsono. 1988. Coaching dan Aspek-Aspek Psikologis Dalam Coaching. Jakarta : Depdikbud Dirjen Dikti

Hermina Sukmaningtyas, Dwi Pudjonarko. Edwin Basjar. 2004. Pengaruh Latihan Aerobik dan Anaerobik terhadap System kardiovaskuler dan Kecepatan Reaksi. Media Medika Indonesia; 39@:h 74-79

Hernawati. Produksi Asam laktat pada Exercise Aerobik dan Anaerobik. Jurusan Pendidikan Biologi FPMIPA Universitas Pendidikan Indonesia. http//:hernawati_hidayat@yahoo.com

Hillbom M. Oxidan, Antioxidan, Alcohol, and Stroke. Fronties in Bioscience 4 e. August 15, 1999: 67-71.

Ina, M., Akyuz, F, Turgut, A, And Getsfridwar. 2001. Effect of Aerobic and Anaerobic Metabolism on Free Radical Generation Swimmers. Medical Science Sports Exercise

Kailaku, I.S., Dewandari, K.T., dan Sunarmani. 2007. Potensi Likopen dalam Tomat untuk Kesehatan. Jurnal Kesehatan, Vol. 3: $51-57$

Kim, H. T., dan Chae, C.H., 2006. Effect of Exercise and $\alpha$-Lipoic Acid Supplementation on Oxidative Stress in Rats. Biology of Sport. 23(2):114-53

Kiyatno, 2009. Antioksidan Vitamin dan Kerusakan Otot pada Aktivitas Fisik Studi Eksperimen pada Mahasiswa JPOK-FKIP UNS Surakarta. Volume 43, Nomor 6, Tahun 2009. Media Medika Indonesia. 
Kuncahyo \& Sunardi, 2007. Uji Aktivitas Antioksidan Ekstrak Belimbing Wuluh (Averrhoa bilimbi, L.) terhadap 1,1-Diphenyl-2-Picrylhidrazyl (DPPH). Seminar Nasional Teknologi 2007 (SNT 2007) ISSN: 1978-9777 Yogyakarta

Leeuwenburgh, C., Heinecke, J.W. 2001. Oxidative Stress and Antioxidants in Exercise. Current Medicinal Chemistry 2001, 8, 829-838 829

Marciniak, A., Brzeszczyńska, J., Gwoździński, K., dan Jegier, A., 2009. Antioxidant Capacity and Physical Exercise. Biology of Sport. 26 (3): 197-213

Mardiah, 2013. Efek Latihan Fisik Intensitas Sedang terhadap Kadar SGOT dan SGPT pada Mahasiswa STIK Siti Khadijah Palembang 2013. Tesis Program Studi Ilmu Biomedik Universitas Sriwijaya.

Margaritis, I., Palazzetti, S., Rousseau, A. S., Richard, M. J. \& Favier, A. (2003), Antioxidant supplementation and tapering exercise improve exercise-induced antioxidant response. $\mathrm{J}$ Am Coll Nutr, 22, 147-56.

Meinvielle, F.J.B. 2005. Superoxide Dismutase (SOD), a Powerful Antioxidant, is now available Orally. Phytothérapie (2005) Numéro 3: 1-4 @ Springer 2005

Patellongi, Ilham Jaya. 2000. Fisiologi Olah Raga. Makasar: Bagian Ilmu Faal, Fakultas Kedokteran Universitas Hasanuddin

Pelley, J. W. 2007. Biochemistry. Mosby Inc. Pennsylvania. p. 55-7

Purnomo, M. 2011. Asam Laktat dan Aktivitas SOD Eritrosit pada Fase Pemulihan Setelah Latihan Submaksimal. Jurnal Media IImu Keolahragaan Indonesia
Volume 1. Edisi 2. Desember 2011. ISSN: 2088-6802

Rohmatussolihat, 2009. Antioksidan, Penyelamat Sel-Sel Tubuh Manusia. Bio Trends/ Vol.4/No.1/Tahun 2009

Rusli, Lutan. 2001. Penanggulangan Cedera Olahraga pada Anak Sekolah Dasar. Jakarta : Ditjen Olahraga

Scandalios, J. G. 2005. Oxidative Stress: Molecular Perception and Transduction of Signals Triggering Antioxidant Gene Defenses. Brazilian Journal of Medicaland Biological Research. 38: 995-014

Sen, S., Chakraborty, R., Sridhar, Reddy \& De. 2010. Free Radicals, Antioxidants, Diseases And Phytomedicines: Current Status And Future Prospect. Volume 3, Issue 1. International Journal of Pharmaceutical Sciences Review and Research.

Sholihah, Q., Widodo, M.A. 2008. Pembentukan Radikal Bebas Akibat Gangguan Ritme Sirkadian dan Paparan Debu Batubara. Jurnal Kesehatan Lingkungan, Vol.4, No.2

Sientina, Fathirina. 2012. Pengaruh Latihan Senam Aerobik terhadap Perubahan Berat Badan pada Peserta Klub Kebugaran. Universitas Diponegoro

Siswanto. 2010. Meningkatkan Kadar Gula Buah Melon. Jawa Timur: UPN Veteran Siswonoto, Susilo. 2008. Hubungan Kadar Malondialdehid Plasma dengan Keluaran Klinis Stroke Iskemik Akut. Program pasca sarjana Magister ilmu biomedik Dan Program pendidikan dokter spesialis IImu penyakit saraf Universitas diponegoro Semarang 
Stejnborn, S. et al. Efffects of Oral Supplementation with Plan Superoxide Dismutase Extract on Selected Redox Parameters and An Inflammatory Marker in a, 2000-m Rowing Ergometer Test. International Journal of Sport Nutrition and Metabolism 2011;124-34.

Suarsana I.N, Wresdiyati T, Suprayogi A. 2013. Respon Stres Oksidatif dan Pemberian Isoflavon terhadap Aktivitas Enzim Superoksida Dismutase dan Peroksidasi Lipid pada Hati Tikus. JITV Vol. 18 No 2 Th. 2013: 146-152

Sukirno. 2012. Dasar-Dasar Atletik dan Ltihan Fisik. Palembang: UNSRI

Sulistyowati Y. 2006. Pengaruh Pemberian Likopen terhadap Status Antioksidan (Vitamin C, Vitamin E dan Gluthathion Peroksidase) Tikus (Rattus Norvegicus Galur Sprague Dawley) Hiperkolesterolemik. Thesis Program Studi Magister IImu Biomedik Program Pascasarjana Universitas Diponegoro

Traber, M. G. 2006. Relationship of Vitamin $E$ Metabolism and Oxidation in Exercising Human Subjects. British Journal of Nutrition. 96 (Suppl.1): 34-7

Wadud, 2013. Pengaruh Aktivitas Fisik Aerobik dan Anaerobik Terhadap Kadar Anti Diureutik Hormon (ADH) dan Elektrolit Darah. Jurnal Program Studi Magister IImu Biomedik Program Pascasarjana Universitas Sriwijaya

Wahyuni, Asja'ri S.R, Sadewa A.H, 2008. Kajian Kemampuan Jus Buah Tomat (Solanum Lycopersicum) dalam Menghambat Peningkatan Kadar Malondyaldehide Plasma setelah Latihan Aerobik Tipe High Impact. Jurnal
Kesehatan, ISSN 1979-7621, VOL. I, NO. 2, DESEMBER 2008, Hal 123-132 Wayan, S.A., 2010. Efek Karotenoid Chlorella pyrenoidosa Terhadap Aktifitas Malondialdehid dan Superoxyd Dismutase pada Sel Darah Merah Domba yang Mengalami Stres Oksidatif. Seminar Nasional Biologi

Winarsi, Hery. 2003. Antioksidan Alami dan Radikal Bebas Potensi dan Aplikasi dalam Kesehatan. Yogyakarta. Kanisius

Wirakusumah, 2000. Manfaat Melon bagi Kesehatan. Jurnal Saint dan Teknologi Vol. 2 No. 2 Januari 2000: 115-135

Yunita, Prabawati S., Setiawan A.F., Agustina A.F. 2012. Sintesis Senyawa1,4-Bis [(2-Hidroksi-3-Metoksi-5-Formaldehid-Fe nil)-Metil] Piperazin dari Bahan Dasar Vanilin dan Uji Aktivitasnya Sebagai Zat Antioksidan. Kaunia,Vol.Viii, No.1

Yunus, M. 2001. Pengaruh Pemberian Vitamin C Terhadap Kerusakan Membran Sel Eritrosit Tikus Wistar Yang Mendapat Latihan Anaerobik. Usulan Penelitian tidak diterbitkan. Surabaya: Program Pasca Sarjana UNAIR

Zelko, I. N., Mariani, T. J. dan Folz, R. J. 2002. Superoxide Dismutase Multigene Family: A Comparison of The CuZn- SOD (SOD1), Mn-SOD (SOD2), and EC-SOD (SOD3) Gene Structure, Evolution, and Expression. Free Radical Biology \& Medicine. 33 (3): 337-49 